Western North American Naturalist 69(3), (C) 2009, pp. 391-395

\title{
NEW RECORD AND SOUTHERN RANGE EXTENSION FOR THE MEARN'S GRASSHOPPER MOUSE (ONYCHOMYS ARENICOLA MEARNS, 1896) IN VERACRUZ, MEXICO
}

\author{
Alvar González-Christen ${ }^{1}$, Christian Alejandro Delfín-Alfonso² ${ }^{2}$ and Alberto González-Romero ${ }^{3}$
}

\begin{abstract}
Mearn's grasshopper mouse (Onychomys arenicola) in Mexico is found primarily in the central and northern states. This is the first report of the genus Onychomys in the state of Veracruz, based on 7 captured specimens ( 3 collected). This finding extends the species' known distribution by approximately $470 \mathrm{~km}$ east-southeast. In addition, this record increases the alpha diversity of terrestrial mammals for the state of Veracruz to 192 species.
\end{abstract}

Key words: grasshopper mouse, Onychomys arenicola, distribution, record, Perote, Veracruz, Mexico.

Mearn's grasshopper mouse (Onychomys arenicola Mearns, 1896) is a polytypic species represented in Mexico by the subspecies $O$. $a$. canus Merriam, 1904 and O. a. surrufus Hollister, 1914 (Ramírez-Pulido et al. 2000, Musser and Carleton 2005). Historically it has been reported infrequently; hence its presence in scientific collections is relatively uncommon (Hinesley 1979, Musser and Carleton 1993, Davis and Schmidly 1997, Clary et al. 1999). In Mexico, there are records of $O$. arenicola in the Chihuahuan Desert and in the states of Durango, Jalisco, San Luis Potosí, Zacatecas, Nuevo León, and Tamaulipas. The southernmost state in which both the species and the genus have been recorded is San Luis Potosí (Riddle and Honeycutt 1990, López-Wilchis and López-Jardines 1998, Ramírez-Pulido et al. 2000, 2005, Villa and Cervantes 2003, Godínez 2005). Mearn's grasshopper mouse inhabits areas of low vegetation on sandy or gravel-covered arid land, where the vegetation is mainly xerophytic shrubs, mesquite, or other shrub species typical of the central plateau of Mexico (Davis and Schmidly 1997, Godínez 2005). Although the species has a wide distribution in the aforementioned areas of Mexico, it has not been previously reported in the central southern states of Querétaro, Guanajuato, Hidalgo, Puebla, Tlaxcala, or Veracruz, even though the habitat preferred by the species occurs in these states.
From 2000 to 2005, 7 specimens belonging to the genus Onychomys were captured in Sherman traps at 5 sites in the Perote Valley, central Veracruz. The sites are $17 \mathrm{~km}$ northwest of Cofre de Perote National Park and very close to the village of El Frijol Colorado in the municipality of Perote (Fig. 1). The climate at the collecting sites is classified as $\mathrm{BS}_{1} \mathrm{kw}\left(\mathrm{i}^{\prime}\right) \mathrm{g}$, the most humid of the semiarid climates (Soto and Angulo 1990). The dominant vegetation is a desert scrub association of Nolina parviflora, Yucca periculosa, Agave obscura, and Distichlis spicata that has been gradually replaced by grassland (Bouteloua hirsuta and Suaeda nigra) and crops. Mean annual temperature is $13.5^{\circ} \mathrm{C}$ but drops to an average of $-3{ }^{\circ} \mathrm{C}$ during the coldest month (González-Christen et al. 2006). Mean annual precipitation is $380 \mathrm{~mm}$, and the average elevation is $2456 \mathrm{~m}$ above sea level. Three specimens were sacrificed, and their skins and skulls were deposited as voucher specimens (Ramírez-Pulido et al. 1989) in the mammal collection (VER-MAM-191-1006) at the Institute of Biological Research, University of Veracruz, Xalapa (Cat. IIB-UV $2594,2767,2604)$. Two specimens were marked and released in situ; 2 others were photographed and released in situ for the photographic catalog (Botello et al. 2007) of the university's collection (IIB-UV 0001f, 0002f; Table 1).

${ }^{1}$ Curator, Laboratorio de Zoología, Instituto de Investigaciones Biológicas, Universidad Veracruzana Avenida Dr. Luís Castelazo S/N, Col. Industrial Animas, C. P. 91190, Km. 3.5 Carretera Xalapa-Veracruz, A. P. 294 Xalapa, Veracruz, Mexico. E-mail: agonzalez@uv.mx

${ }^{2}$ Departamento de Ecología Aplicada, Instituto de Ecología, A.C. Km. 2.5 Antigua Carretera a Coatepec No. 351 Congregación "El Haya," C. P. 91070 , A. P. 63 Xalapa, Veracruz, Mexico.

${ }^{3}$ Departamento de Biodiversidad y Ecología Animal, Instituto de Ecología, A.C. Km. 2.5 Antigua Carretera a Coatepec No. 351 Congregación "El Haya," C. P. 91070, A. P. 63 Xalapa, Veracruz, Mexico. 


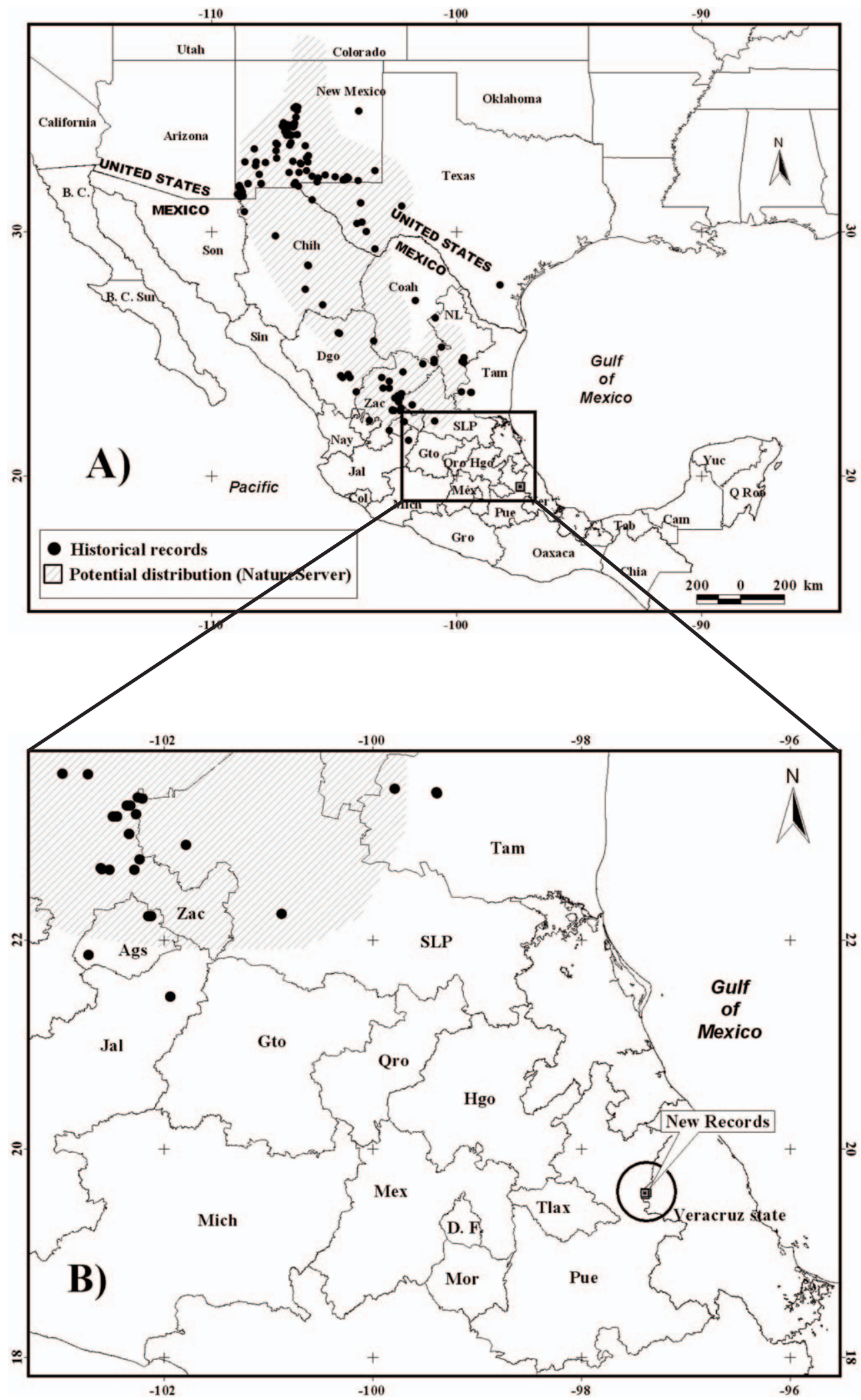




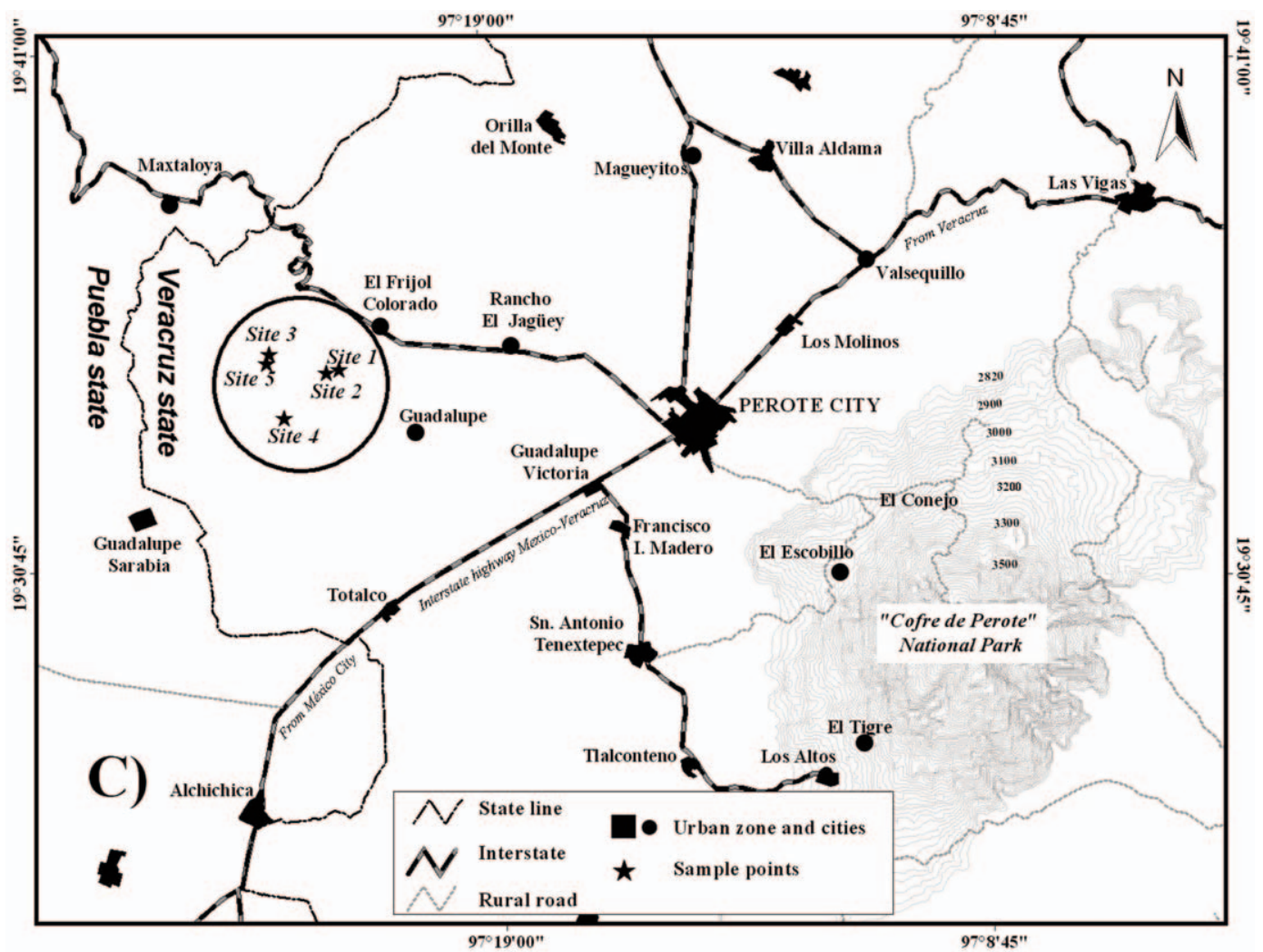

Fig. 1. Onychomys arenicola in North America (NatureServe 2004): A (facing page), potential distribution and historical records (biodiversity occurrence data provided by and accessed through the GBIF data portal [GBIF 2007]); B (facing page), records closest to Veracruz; and C (above), collecting sites in central Veracruz, Mexico.

TABLE 1. Collecting sites for Onychomys arenicola in the Perote Valley, Veracruz, Mexico. Catalog number (Cat).

\begin{tabular}{|c|c|c|c|c|c|c|}
\hline Site & Cat. & Date & Latitude & Longitude & Localities & Type of record \\
\hline 1 & 2604 & & & & & \\
\hline 1 & No data & & & $97^{\circ} 21$ & & \\
\hline 2 & 2594 & & & $97^{\circ} 21$ & & nen \\
\hline & $\mathrm{N}$ & & & & & \\
\hline & & & & $97^{\circ} 23$ & ado & Vor \\
\hline & $01 \mathrm{f}$ & Oct & $19^{\circ} 33$ & $97^{\circ} 22^{\prime} 47.56^{\prime \prime}$ & 4.01 km SW of El Frijol Colorado & Photograph/release \\
\hline 5 & $0002 f$ & 06 Oct 2004 & $19^{\circ} 34^{\prime} 56.82^{\prime \prime}$ & $97^{\circ} 23^{\prime} 08.70^{\prime \prime}$ & $3.65 \mathrm{~km}$ WSW of El Frijol Colorado & Photograph/released \\
\hline
\end{tabular}

We took 5 body measurements and 20 cranial and jaw measurements of the voucher specimens (Table 2) using a Mitutoyo digimatic caliper (precision $0.01 \mathrm{~mm}$; Gaona 1997). The specimens were identified as $O$. arenicola using identification keys and a specialized bibliography (Hinesley 1979, Hall 1981, Davis and Schmidly 1997). These new records for $O$. arenicola extend the known distribution of the species toward the central region of the state of Veracruz, as far west as its border with the state of Puebla (Fig. 1). The previous southernmost collecting site is $470 \mathrm{~km}$ west-northwest (straight-line distance) from the new record in Veracruz. There, 14 specimens were collected $16 \mathrm{~km}$ northeast of San Luis Potosí in the municipality of Soledad de Graciano Sánchez (GBIF 2007).

The occurrence of $O$. arenicola in the state of Veracruz increases the cumulative alpha diversity of terrestrial mammals in that state to 192 species (Gaona et al. 2003, González-Christen 
et al. 2002, 2006). The presence of Mearn's grasshopper mouse in central Veracruz merits further research. In addition to conducting genetic studies on the population, it is also important to define the population's geographical distribution (Musser and Carleton 2005). Increased collection effort is recommended for the states of Querétaro, Puebla, Tlaxcala, and Veracruz; this effort would produce records that would be helpful in defining the ecological niche of the Mearn's grasshopper mouse (Anderson and Martínez-Meyer 2004), and this, in turn, would facilitate identification of areas critical to its conservation and management.

\section{Literature Cited}

Anderson, R.P., and E. Martínez-Meyer. 2004. Modeling species' geographic distributions for preliminary conservation assessments: an implementation with the spiny pocket mice (Heteromys) of Ecuador. Biological Conservation 116:167-179.

Botello, F, G. Monroy, P. Illoldi-Rangel, I. TrujilloBolio, AND V. SÁNCHEZ-CoRdERO. 2007. Sistematización de imágenes obtenidas por fototrampeo: una propuesta de ficha. Revista Mexicana de Biodiversidad 78:207-210.

Clary, M.L., D.M. BelL, C.W. EdWards, T.W. Jolley, O. KNYAZHNitskiY, N. LeWIS-ORITT, S.J. MantoOTH, L.L. Peppers, I. Tiemann-Boege, F.D. Yancy, II, et AL. 1999. Checklist of mammals from twelve habitat types at Fort Bliss Military Base; 1997-1998. Occasional Papers of the Museum of Texas Tech University 192: $i+1-16$.

DaVIS, W., AND D. SChMidLy. 1997. The mammals of Texas, online edition: Mearn's grasshopper mouse. Available from: http://www.nsrl.ttu.edu/tmotl/onycaren.htm [accessed 28 May 2007].

GaONA, S. 1997. Variación no geográfica de Peromyscus difficilis (Rodentia: Muridae) en la región noroeste de la Cuenca Oriental en Puebla y Veracruz, México. Pages 135-156 in J. Arroyo-Cabrales and O. Polaco, editors, Homenaje al Profesor Ticul Álvarez. Instituto Nacional de Antropología e Historia, Colección Científica, México.

GAONA, S., A. GONZÁLEZ-Christen, AND R. LÓPEZ-WiLChIS. 2003. Síntesis del conocimiento de los mamíferos silvestres del Estado de Veracruz, México. Revista de la Sociedad Mexicana de Historia Natural $3^{\text {a }}$ Epoca. $1: 91-124$.

GBIF. 2007. GBIF data portal. Available from: http://www .gbif.org [accessed 21 May 2007].

Godínez, H. 2005. Onychomys arenícola Mearns, 1896. Pages 704-705 in G. Ceballos and G. Oliva, editors, Los mamíferos silvestres de México. CONABIOFondo de Cultura Económica.

González-Christen, A., S. GaOna, ANd G. López-Ortega. 2002. Registros adicionales de mamíferos para el Estado de Veracruz. Vertebrata Mexicana 11:9-17.

González-Christen, A., A. González-Romero, and J.S. Rodríguez-Colmenares. 2006. Primer registro de Taxidea taxus berlandieri Baird, 1858 (Mammalia: Carnivora: Mustelidae) para el Estado de 
Veracruz, México. Acta Zoológica Mexicana (n.s.) 22(3):153-156.

HaLl, E.R. 1981. The mammals of North America. 2nd edition. Volume 2. John Wiley \& Sons, New York.

Hinesley, L. 1979. Systematics and distribution of two chromosome forms in the southern grasshopper mouse; genus Onychomys. Journal of Mammalogy 60:117-128.

NatureServe. 2004. InfoNatura: birds, mammals, and amphibians of Latin America [web application]. Version 4.1. NatureServe, Arlington, VA. Available from: http://www.natureserve.org/infonatura [accessed 20 May 2007].

López-Wilchis, R., and J. LóPEZ-JaRdines. 1998. Los mamíferos de México depositados en colecciones de Estados Unidos y Canadá. Volume 1. Universidad Autónoma Metropolitana Unidad Iztapalapa, México, D. F. 323 pp.

Musser, G., and M.D. Carleton. 1993. Family Muridae. Pages 501-755 in D.E. Wilson and D.M. Reeder, editors, Mammal species of the world: a taxonomic and geographic reference. 2nd edition. Smithsonian Institution Press, Washington DC.

2005. Superfamily Muroidea. Pages 894-1531 in D.E. Wilson and D.M. Reeder, editors, Mammal species of the world: a taxonomic and geographic reference. 3rd edition. Johns Hopkins University Press, Baltimore, MD.
Ramírez-Pulido, J., J. Arroyo-Cabrales, and A. CastroCAMPILlO. 2005. Estado actual y relación nomenclatural de los mamíferos terrestres de México. Acta Zoológica Mexicana (n.s.) 21(1):21-82.

Ramírez-Pulido, J., A. Castro-Campillo, M.A. Armella, AND A. SaLAme-MÉnDEz. 2000. Bibliografía reciente de los mamíferos de México 1994-2000. Universidad Autónoma Metropolitana, México, D. F. 280 pp.

Ramírez-Pulido, J., I. Lira, S. Gaona, C. Müdespacher, and A. Castro-Campillo. 1989. Manejo y mantenimiento de colecciones mastozoológicas. Universidad Autónoma Metropolitana-Unidad Iztapalapa, México, D. F. 127 pp.

Riddle, B.R., and R.L. Honeycutt. 1990. Historical biogeography in North American arid regions: an approach using mitochondrial-DNA phylogeny in grasshopper mice (genus Onychomys). Evolution $44: 1-15$.

Soto, M., And Ma. DE Jesús Angulo. 1990. Estudio climático de la región del Cofre y Valle de Perote. Instituto de Ecología A.C., Jalapa, México.

Villa, R.B., AND F.A. CERvantes. 2003. Los mamíferos de México. Instituto de Biología, UNAM y Grupo Editorial Iberoamérica. México, D. F. 140 pp.

Received 14 September 2007 Accepted 17 March 2009 